\title{
A comparison of serological tests for the diagnosis of gonorrhoea
}

\author{
P. J. WATT, M. E. WARD, AND A. A. GLYNN \\ Bacteriology Department, Wright-Fleming Institute, St. Mary's Hospital Medical School, London, W.2
}

In recent years the rapid increase in the incidence of gonorrhoea has led to a renewed interest in serological diagnosis. A reliable test would permit the large-scale search for asymptomatic carriers among those sections of the population at particular risk and could help to control the disease. Such a test would be invaluable in circumstances in which genital examination of women is difficult or cultural methods inadequate. Several possible serological tests have recently been described, but it is difficult to compare their relative merits in the absence of a standardized collection of positive and control sera. We have therefore compared three of the most promising tests (Magnusson and Kjellander, 1965; Reising, Schmale, Danielsson, and Thayer, 1969; Wallace, Diena, Yugi, and Greenberg, 1970) against the same collection of sera, and have investigated the possibility of using gonococcal lipopolysaccharide-coated latex particles as an antigen for the detection of gonococcal antibody.

\section{Material and methods \\ SERA}

Serum was collected from eighty men with clinical and microscopical evidence of gonorrhoea and from 37 women with positive cultures for gonococci. Control sera were obtained from 33 laboratory personnel and students who specifically denied ever having suffered from gonorrhoea. The sera were given a random code number and then stored frozen at $-20^{\circ} \mathrm{C}$.

\section{BACTERIA}

The gonococci used in the preparation of antigens for this study were of colony type 1 (Kellogg, Peacock, Deacon, Brown, and Pirkle, 1963). Strains DA1 and DA2 were fresh isolates, while the established laboratory strain F62 was kindly provided by Dr. D. S. Kellogg. After the minimal subculture needed to ensure purity, the strains were preserved in liquid nitrogen (Ward and Watt, 1971). For bulk growing the pellets were rapidly thawed and directly inoculated onto plates of colonial-type indicator medium (White and Kellogg, 1965). A further seventeen

Received for publication May 25, 1971 freshly isolated gonococcal strains were used to prepare the gonococcal complement-fixation antigen described by Magnusson and Kjellander (1965).

\section{ANTIGEN PREPARATION}

After 36 hrs' incubation, the gonococci were washed off the plates and suspended in distilled water, and the cells were disrupted in an X-press (Biotech.). After centrifugation at $36,000 \mathrm{G}$. for $1 \mathrm{hr}$, the lyophilized supernatant was fractionated on DEAE-Sephadex and the $0.4 \mathrm{M}$ antigen collected (Schmale, Danielsson, Smith, Lee, and Peacock, 1969). The cell wall debris was extracted with phenolwater and the aqueous phase used for the preparation of lipopolysaccharide (Maeland, 1968). The phenol-phase was used for the preparation of the bentonite sensitizing? antigen described by Wallace and others (1970).

\section{SEROLOGICAL TESTS}

Lipopolysaccharide was treated with alkali (Davies, Crumpton, Macpherson, and Hutchison, 1958), adjusted to a concentration of $15 \mu \mathrm{g} . / \mathrm{ml}$. in phosphate buffered saline $\mathrm{pH} 7.3$ (PBS), and incubated for $2 \mathrm{hrs}$ at $37^{\circ} \mathrm{C}$. with 1 per cent. by volume of Bacto Latex 0.81 (Difco). Doubling dilutions of the sera were prepared in PBS using the Microtiter system (Cooke Engineering). An equal volume of sensitized latex was added to each well, the trays were incubated for $2 \mathrm{hrs}$ at $37^{\circ} \mathrm{C}$., and the agglutination pattern was read after a further $24 \mathrm{hrs}$ at $4^{\circ} \mathrm{C}$. Controls consisting of unsensitized latex in serum from normal and infected individuals were routinely included. Bentonite flocculation and complement-fixation tests were carried out as described by the original workers (Wallace and others, 1970; Magnusson and Kjellander, 1965; Reising and others, 1969). All tests were read 'blind' by two independent observers.

\section{Results}

The ability of latex coated with various lipopolysaccharides to detect specific antibody in patients with gonococcal infections is shown in Table I. Using lipopolysaccharides from all three strains, the percentage of patients with serum titres exceeding $1: 8$ was obviously greater than that of the controls. However, at least 15 per cent. of the control sera were positive by this criterion. The fact that lipopoly- 
TABLE I Agglutination test using latex spheres coated with gonococcal lipopolysaccharide (LPS)

\begin{tabular}{llll}
\hline & \multicolumn{3}{l}{$\begin{array}{l}\text { Percentage of individuals with serum } \\
\text { titres exceeding } 1: 8\end{array}$} \\
\cline { 2 - 4 } Gonococcal LPS tested & Controls & $\begin{array}{l}\text { Infected } \\
\text { females }\end{array}$ & $\begin{array}{l}\text { Infected } \\
\text { males }\end{array}$ \\
\hline F 62 & 15 & 54 & 46 \\
DA 1 & 15 & 51 & 35 \\
DA 2 & 63 & 89 & 80 \\
\hline
\end{tabular}

saccharide from strain DA2 was less discriminating than that from F62 or DA1 suggests some strain specificity.

A possible explanation for the high incidence of positive results in controls is that alkali treatment of lipopolysaccharide, by removing sugars and 0acetyl groups (Čižnár and Shands, 1970), reduces its antigenic specificity. However, we obtained identical results when the test was repeated using lipopolysaccharide disaggregated with ultra-sound rather than with alkali. Using the method described by Makinodan and Petersen (1966), we found that the agglutinating antibodies in the positive sera from both patients and controls were sensitive to 2 mercaptoethanol and were, therefore, $\gamma M$.

Rabbit antigonococcal sera specifically agglutinated bentonite coated with a protein antigen prepared from the phenol-phase of the lipopolysaccharide extraction (Wallace and others, 1970). However, unlike Wallace and his colleagues, we found that sera from both patients and controls agglutinated the sensitized bentonite at a high titre. A possible explanation for this difference in results is that we used the solid material obtained after rupturing gonococci in an X-press rather than whole cells. Nevertheless, Maeland (1969) found that proteins extracted from gonococci by aqueous ether were group reactive antigens common to both meningococci and gonococci.

Table II compares the results of the complementfixation test devised by Reising and others (1969) with our study. The purified protoplasmic antigen was prepared from the same strain, F62, by the methods described by these workers. In both studies the percentage of male and female patients with a positive test was almost identical. However, Reising and his colleagues were unable to detect antibody in any of their control sera, whereas we found that 12 per cent. of controls gave positive results. Again, the strain used to prepare the antigen was important because protoplasmic antigen prepared from strains DA1 or DA2 showed little discrimination between patients and control sera. Using the gonococcal complement-fixation test described by Magnusson
TABLE II Comparison of the results of the complement-fixation test of Reising and others (1969) with the present study using purified 'protoplasmic' antigen from gonococcal strain $F 62$

\begin{tabular}{llll}
\hline & \multicolumn{2}{l}{$\begin{array}{l}\text { Percentages of individuals giving } \\
\text { positive results }\end{array}$} \\
\cline { 2 - 3 } Gonococcal strain & Controls & $\begin{array}{l}\text { Infected } \\
\text { females }\end{array}$ & $\begin{array}{l}\text { Infected } \\
\text { males }\end{array}$ \\
$\begin{array}{l}\text { Reising and others (1969) } \\
\begin{array}{l}\text { Titre }>1: 2 \\
\text { St. Mary's }(1971)\end{array}\end{array}$ & 0 & 72 & 20 \\
Titre $>1: 4$ & 12 & 71 & 17 \\
\hline
\end{tabular}

TABLE III Comparison of the results of the gonococcal complement-fixation test of Magnusson and Kjellander (1965) with the present study

\begin{tabular}{|c|c|c|c|}
\hline \multirow{2}{*}{ Gonococcal strain } & \multicolumn{3}{|c|}{$\begin{array}{l}\text { Percentage of individuals giving } \\
\text { positive results }\end{array}$} \\
\hline & Controls & $\begin{array}{l}\text { Infected } \\
\text { females }\end{array}$ & $\begin{array}{l}\text { Infected } \\
\text { males }\end{array}$ \\
\hline \multicolumn{4}{|c|}{$\begin{array}{l}\text { Magnusson and Kjellander } \\
(1965)\end{array}$} \\
\hline $\begin{array}{l}\text { Titre > } 1: 4 \\
\text { St. Mary's }(1971)\end{array}$ & 6 & 62 & 19 \\
\hline Titre $>1: 5$ & 8 & 62 & 39 \\
\hline
\end{tabular}

and Kjellander (1965), we obtained results virtually identical with the original report (Table III).

\section{Discussion}

An ideal serological test for the detection of asymptomatic reservoirs of gonococcal infection in the population must be both highly specific and very sensitive. Any test which gave even a small percentage of false positive results would lead to the detection of unmanageable numbers of normal individuals all requiring careful follow-up. None of the tests examined in the present study gave a sufficiently low incidence of false positive results to be of value in population screening. However, two tests, those of Reising and others (1969) and Magnusson and Kjellander (1965), which gave positive results in 12 and 8 per cent. respectively of control sera, would be useful ancillary aids in the diagnosis of gonorrhoea in female patients. The antigen used in the Magnusson and Kjellander gonococcal complement-fixation test is easy and cheap to prepare and the test gave the lowest incidence of false positive results, but it detected fewer positive sera amongst infected women.

There are still problems to be overcome in the preparation of the antigen used in the Reising test because the final purified antigen was weight for weight less active serologically than the original crude 'protoplasm' extract (Reising and others, 1969). 
Our own observations show that, although the purified antigen runs as a single peak when rechromatographed on DEAE-Sephadex, it still consists of a mixture of carbohydrate and protein with traces of nucleic acids and can be split into more than one band on polyacrylamide electrophoresis.

The agglutination test with endotoxin-coated latex gave some discrimination between patient and control sera. As with the complement-fixation tests, the sera from female patients were more often positive than sera from infected men. This is to be expected because the duration of infection in women, though often unknown, may be prolonged. Despite this it is likely that little specific antibody is produced in asymptomatic females so that a highly sensitive test is needed. Such a test may well lack specificity as is shown by our results. Using the same complementfixation test we obtained 12 per cent. of false positive results in our control group compared with none among the controls used by Reising and his colleagues. Obviously 12 per cent. of our controls were not suffering from gonorrhoea and we believe that the false positive results were due to cross-reacting antibodies. Nevertheless, it is important to establish the duration of the antibody response after infection with gonorrhoea before serological testing can be used to diagnose active disease.

Our results show clear evidence of strain specificity with both lipopolysaccharide and the protoplasm antigen used in the Reising test. There is already evidence in the literature of strain specificity due to determinants on the polysaccharide component of gonococcal lipopolysaccharide (Maeland, 1969; Glynn and Ward, 1970). Danielsson, Schmale, and Lee (1970), using the purified protoplasmic antigen, found that some patients' sera gave a positive result only with antigen isolated from their own gonococcal strain, again indicating the importance of strain specificity. Unfortunately, most investigations into the diagnostic usefulness of gonococcal antigens have used a single strain. An exception to this is the antigen for the complement-fixation test of Magnusson and Kjellander which consists of a pool of twenty strains. Careful selection of the individual strains used may improve the specificity of this test.

Although there is overwhelming evidence of an antibody response in both acute and asymptomatic gonorrhoea, the tests in use lack both specificity and sensitivity. A careful study of the immunochemistry of gonococci may ultimately prove more rewarding for the diagnostician than the blind trial of crude extracts.

\section{Summary}

Four different serological tests for the diagnosis of gonorrhoea have been compared on the same collection of patient and control sera. The complementfixation tests devised by Magnusson and Kjellander (1965) and by Reising and his colleagues (1969) gave positive results in 8 and 12 per cent. of control individuals, 62 and 71 per cent. of infected women, and 39 and 17 per cent. of infected men respectively. An agglutination test using gonococcal lipopolysaccharide adsorbed onto latex particles gave positive results in 15 per cent. of controls, 54 per cent. of infected women, and 46 per cent. of infected men. The purified antigens used showed evidence of strain specificity. We were unable to discriminate between patient and control sera using the Wallace bentonite flocculation test, even though specific agglutination was obtained with rabbit antigonococcal sera.

It is concluded that the Magnusson and Kjellander test can be a useful adjunct in the diagnosis of gonorrhoea. However, the level of false positive results in all the tests is too high to permit their use in screening for asymptomatic reservoirs of infection in the population.

We thank the World Health Organization for financia support and the Venereal Diseases Department, $S$ Mary's Hospital, London, W.2, who kindly provided the patients' sera. We are glad to acknowledge the excellen technical assistance given by Mrs. T. McKay.

\section{References}

ČIžNÁR, I., and SHANDS, J. W. (1970) Infect. and Immunity 2, 549

Danielsson, D., Schmale, J. D., and Lee, L. (1970) Acta path. microbiol. scand., 78B, 267

Davies, D. A. L., Crumpton, M. J., Macpherson, I. A., and Hutchison, A. M. (1958) Immunology, 1, 157

GLYNN, A. A., and WARD, M. E. (1970) Infect. and Immunity, 2, 162

Kellogg, D. S., Peacock, W. L., Deacon, W. E., Brown, L., and PIRKLE, C. I. (1963) f. Bact., 85, 1274

Maeland, J. A. (1968) Acta path. microbiol. scand., 73, 413 - (1969) Ibid., 77, 505

MAGNusson, B., and KJELLANDER, J. (1965) Brit. F. vener. Dis., 41, 127

Makinodan, T., and Petersen, W. J. (1966) Develop. Biol., 14, 112

Reising, G., Schmale, J. D., Danielsson, D. G., and Thayer, J. D. (1969) Appl. Microbiol., 18, 337

Schmale, J. D., Danielsson, D. G., Smith, J. F., Lee, L., and PEACOCK, W. L. (1969) f. Bact., 99, 469

Wallace, R., Diena, B. B., YUgi, H., and GREenberg, L. (1970) Canad. F. Microbiol., 16, 655

WARD, M. E., and WATT, P. J. (1971) F. clin. Path., 24,122

White, L. A., and Kellogg, D. S. (1965) Appl. Microbiol., 13, 171 


\section{Comparaison de diverses épreuves sérologiques pour le diagnostic de la gonococcie}

\section{SOMMAIRE}

Quatre épreuves sérologiques différentes proposées pour le diagnostic de la gonococcie ont été comparées sur les mêmes sérums d'une série de malades et de contrôles. Les tests de fixation du complément décrites par Magnusson et Kjellander (1965) et par Reising et ses collaborateurs (1969) ont donné des résultats positifs, respectivement, dans 8 et 12 pour cent des sujets témoins, dans 62 et 71 pour cent des femmes infectées et dans 39 et 17 pour cent des hommes infectés. Une épreuve d'agglutination utilisant un lipopolysaccharide de gonocoque adsorbé sur des particules de latex a donné des résultats positifs chez 15 pour cent des témoins, 54 pour cent des femmes infectées, et 46 pour cent des hommes infectés. Les antigènes purifiés utilisés mirent en évidence une spécificité de souche. Nous n'avons pas pu distinguer les sérums des malades et des témoins vis-à-vis des épreuves de floculation de la bentonite de Wallace, même lorsqu'une agglutination spécifique avait été obtenue avec des sérums de lapins préparés vis-à-vis du gonocoque.

On conclut que l'épreuve de Magnusson et Kjellander peut être une aide utile dans le diagnostic de la gonococcie. Cependant, pour toutes ces épreuves, la proportion de résultats faussement positifs est trop élevée pour recommander leur emploi dans la recherche systématique des réservoirs d'infection asymptomatiques dans la population. 